\title{
Methodological Framework of CONTEMPORARY Propaganda in the Case of Post-Soviet Countries of Caspian Sea Region
}

\author{
Azer Binnatli \\ Vytautas Magnus University. Lithuania (but a citizen of Azerbaijan)
}

\begin{abstract}
.
Development of social media creates possibility governments to access society easily. Oil and gas resources in post-soviet countries of the Caspian Sea region, make this region the focal point of propaganda campaigns. Therefore, the main aim of the paper is to create a map of contemporary propaganda by investigating its characteristics, tools and types and strategies, limitation and applying to the post-soviet countries of the Caspian Sea Region. The main definition of propaganda is investigated with theoretical analysis method. In the empirical part, the paper analyses disinformation, fake news, trolls, videos as propaganda strategy of governments in the case of post-soviet countries of the Caspian Sea Region. Qualitative content analysis is useful to investigate news, texts, videos, and images shared on social media. Descriptive analysis is set up to research multiplicity of propaganda campaigns in the mentioned region. Structured interview method will be used with propaganda experts to analyse their opinion on contemporary propaganda and persuasion.

To summarise, propaganda campaigns are more persuasive according to new technologies. There is no doubt that its working principles will evolve as time goes on. This paper investigates the working principles of contemporary propaganda in the case of post-soviet countries of the Caspian Sea Region. Thus, this work is hoped to create a framework for further analysis of the methodology of contemporary propaganda.
\end{abstract}

Keywords: Russia, Kazakhstan, Persuasion, Trolling, Turkmenistan 


\section{International Academic Conference on Research in SOCIAL SCIENCES}

\section{Introduction}

Propaganda is already a familiar phenomenon in society. According to political scientist Harold Laswell, propaganda "is the management of collective attitudes by the manipulation of significant symbols." (Lasswell,1927). Another definition is that "Propaganda is activities, and communications from a government to its citizens, other governmental personnel, or foreign audiences in general." (Speier, 1950) There is a huge gap between classic and contemporary propaganda. Most people use social media like Facebook, Instagram, Twitter, and so on. Using the same platforms makes the possibility for the government to reach members of society straightforwardly. The main reason why people are the victim of this manipulation is that they are not aware of information, whether it is false or right. The majority of social media users accept information as a true they face without fact-checking. The believers of misinformation have a huge impact on others. This is the way how government spread disinformation between people in social media.

As a result of development in technology, Russian propaganda campaigns became more sophisticated. For instance, during the 2016 USA presidential elections, more than 50,000 Russia-linked bots were used to change the tendency of online voting. Also, the troll factory of Russia affected the public mind of Americans. (Hindman \& Barash, 2018) As has been seen, contemporary propaganda is more active and sophisticated than the traditional one. Thus, this paper investigated characteristics, tools and types and strategies, limitation and of modern propaganda by analysing it in the case of post-soviet countries of the Caspian Sea Region. The reason why this region has been selected as a case in this paper is rising interests in this region because of its natural oil and gas. (Fletcher et al., 2018) Different policies in Azerbaijan, Russia, Turkmenistan, Kazakhstan requires plenty of propaganda strategies. The multiplicity of the propaganda campaigns allows researchers to analyse tools, strategies, techniques, limitations of modern propaganda in the wide sense.

The research object is to analyse the main work principles of a contemporary propaganda campaign in the post-soviet countries of the Caspian Sea Region

The main aim is to create a map of contemporary propaganda by investigating its characteristics, tools and types and strategies, limitation and applying to the post-soviet countries of the Caspian Sea Region.

\section{Objectives:}

1. to research the main strategies, techniques, characteristics, limitations of propaganda and manufacturing of consent. 


\section{International Academic Conference on Research in SOCIAL SCIENCES}

2. To analyse the efficiency of propaganda in post-soviet countries of the Caspian Sea region

3. To create a map of contemporary propaganda in the 21 st century in the case of those countries

4. To give a conclusion as an evaluation of research.

Research Method. The definition of propaganda is investigated with theoretical analysis method. In the empirical part, the paper analyses disinformation, fake news, trolls, videos as propaganda strategy of governments in the case of post-soviet countries of the Caspian Sea Region. Qualitative content analysis is useful to investigate news, texts, videos, and images shared on social media. Descriptive analysis is set up to research multiplicity of propaganda campaigns in the mentioned region. Structured interview method will be used with propaganda experts to analyse their opinion on contemporary propaganda and persuasion.

\section{“Russia Today" as a Propaganda Machine}

Russia is a big factory which uses social media as propaganda. The progovernmental mainstream media of Russia named Russia Today (RT) is an international TV funded by the Russian government. (Paul \& Mathews, 2016). The program schedules of RT International includes around-the-clock news bulletins, documentaries, talk shows, debates, sports news, and cultural programmes which interpret global events in the view of Russia. RT broadcasts those contents in English, French, German, Spanish, Russian, and some Eastern European languages. The channel is claimed to have more than a billion page views. (Pomerantsev \& Weiss, 2014). RT known as the main information source in Russia, Caucasus, Caspian region broadcasts news which carries propaganda purposes (Paul \& Mathews, 2016). RT don't hold only anti-western propaganda, also attempt to create fear on the other countries of this Caspian Sea region to prevent any further alliance with Europe which contrasts to the interests of Kremlin. For instance, after some minutes Kazakhstan's President Nursultan Nazarbayev spoke about his resignation live on Facebook, RT media shared this news on the website and later on Facebook and Twitter under the title "Kazakhstan to remain Russia's key ally after Nazarbayev resigns as president." (Russia Today, 2019) In a personal interview with Professor Gintautas Mazeikis, he noted that in this region, all this information is not for a large audience. For Russia and Kazakhstan, the most important thing here is the peaceful transformation of power. Thus, the main target is elites who get $80 \%$ or $90 \%$ of benefits relationship between Russia and Kazakhstan. (G. Mazeikis, personal communication, March 25, 2019) 


\section{International Academic Conference on Research in SOCIAL SCIENCES}

Contemporary Russian propaganda is continuous and very responsive to events. Because they do not reflect objective reality to mass, Russian propagandists do not do factchecking to confirm the truth of news; they propagate an interpretation of breaking news in favour of their interests. This strategy creates an image of RT as a media channel broadcasts news firstly. RT repeated the same news above mentioned with different titles, keywords and interpreted according to their wishes. So if the people hear any information from others about the resignation of Nazarbayev, they will search it on Google. RT will be on the top among results because they shared this news firstly and repeated. So the majority of the audience will trust their interpretations. Shortly, first impressions are very effective (Paul \& Mathews, 2016). According to Begg, Ian Maynard, Ann Anas, and Suzanne Farinacci, repeated information creates a more truthful image of news in the mind of the audience. Also, repeated statements are more believable than new ones. It was called "illusory truth effect" by Hasher Lynn, David Goldstein, and Thomas Toppino (Hasher et al., 1977). People those who don't have knowledge about the topic, they tend to believe information repeated many times in news channels. The audience who doesn't have time and energy for fact-checking, trust the news sources by giving the argument that they heard information frequently (Begg et al., 1992) In a personal interview May 16, 2019, Professor and activist of Human Rights Robert Van Voren noted that Putin announced that Russia lost 20-30 million population during $2^{\text {nd }}$ World War. However, the majority of the population was from Ukraine and Belarussia. The audience believed it because they don't check facts (R. V. Voren, personal communication, May 16, 2019).

Accordingly, in the news about Nazarbayev with the title "Kazakhstan to remain Russia's key ally after Nazarbayev resigns as president" RT stressed that alliance of Russia and Kazakhstan had benefit \$17,6 billion last year. Also, according to interpretations of professor in the Commonwealth of the Independent States named Aza Migranyan, breaking off relations with Russia would be against economical interests of Kazakhstan. Political scientist Vladimir Kornilov's comment also has been placed in this news: "by passing power to people closely connected to him, Nazarbayev expects that there'll be no significant changes in foreign and domestic policy, at least in the coming years" (Russia Today, 2019) as it is obvious to see that the main aim of this news is to manipulate Kazakhstanis by sending the message that keeping relations with Russia will give benefits to them. The context of news attempt to create fear and uses statistics on Kazakhstani audience and next president, that there will be a problem for them if Kazakhstan break relations with Russia. The statements which include emotional feelings such as fear, happiness, are more convincing (Paul \& Mathews, 2016). Also, to strengthen the persuasiveness of news, opinions of political experts such as Aza Migranyan, Vladimir Kornilov and statistic of economic benefits were utilized. According to Petty, R.E., Cacioppo, J.T., Strathman, A.J. and Priester, J.R "peripheral cues" is another factor in 


\section{International Academic Conference on Research in SOCIAL SCIENCES

increasing the reliability of the information (Petty et al., 2005). Information consists of peripheral cues such as simple claims of experts makes people trust source even without fact-checking (McCroskey \& Young, 1981).

\section{Counterpropaganda against Meydan TV}

Unlike pro-governmental media channels, anti-governmental ones are the target of propaganda campaigns. Meydan TV is famous online media channel in Azerbaijan. It has accounts on social media like Facebook, Instagram, Twitter, and YouTube, where the followers are mostly people who are not satisfied with current authority and posts essentially anti-governmental comments. Beside them, actions of trolls are visible. Troll is abused harassed messages, posts, comments against other users' opinion. (Bradshaw \& Howard, 2017). They create fake news, different humiliating contents about admin to spread between users. The trolls I've researched often write derogatory comments intended for admin and the opinion of users such as calling them traitor, liars who are a threat to the stability of Azerbaijan. Some of them attempt to prove baselessness of shared news by analyzing its content and sources, giving an absurd argument about spuriousness of news, in conclusion, trolls call these posts as false, insubstantial, provocation, propaganda. For instance, one translated version of troll comment:

"There are external powers that do not want to see the independent Azerbaijan state strong. They are spreading false, unfounded information and are holding provocation against Azerbaijan, Azerbaijan people. We must stand against this propaganda against our country."

As it has been seen in this comment, troll tries to inject fear on opposite users by showing Meydan TV as an external threat for the independence of Azerbaijan. Thus, "angry messages are more persuasive on the audience" (Desteno et al., 2004). Also, in the last sentence, troll attempt to arise a patriotic feeling of other users by stating to come together fight for the propaganda of external interests who don't want to see Azerbaijan as an independent country. There are three steps of trolling:

1st. Bait. The troll baits the target.

2nd. Reaction - target gives the desired reaction. After many discussions are held, the news is spread within society

3rd. Reveal - the truth reveals. Finally, after fact-checking, it is revealed that bombshell of troll is dud (Paul \& Matthew, 2016). 


\section{International Academic Conference on Research in SOCIAL SCIENCES}

The fake news makes people have a suspect on the honesty of the person. For instance, information that Meydan TV is funded by the government was spread and there were some documents about the transfer of money to account Meydan TV. This is a huge shock for the reputation of that media channel. Even after somewhile this news is discredited, several numbers of people will have suspect on the honesty of Meydan Tv. Thorson Emily calls it "Belief Echoes." According to her, the "one reason why people keep believing the false statement is a high cost to accepting evidence that contradicts our beliefs" (Thorson, 2016). According to Paul Christopher and Miriam Matthews "Information that is initially assumed valid but is later retracted or proven false can continue to shape people's memory and influence their reasoning." (Paul \& Matthew, 2016). If an individual is affected by misinformation, he or she will likely not to accept new information. Even members of his or her group trusted the same disinformation; there is very little chance that affected members of the group will go against their belief.

The reason why disinformation is effective is that people are lazy to check information from different sources. The readers take the majority of information they have seen on social media as true, or they are weak to discriminate false information from true. According to Paul Christopher and Miriam Matthews "Even when people are aware that some sources (such as political campaign rhetoric) have the potential to contain misinformation, they still show a poor ability to discriminate between information that is false and information that is correct" (Paul \& Matthew, 2016). If the information is provided with evidence such as witnesses of the emergent event, it will be more truthful even it is false, which make difficulty for the audience to understand its falsity.

Disinformation spread among the people, users of social media through cyber troops such as government-based trollers, politicians and parties, private contractors, volunteers, paid citizens who are real individuals (Bradshaw \& Howard, 2017). However, the bots are a software application which automatically has their tasks (De Paoli 2016). They create contents which include disinformation, fake news, memes. On Twitter, Facebook bots share plenty of political messages. For instance, 50000 Russia-linked bots affected the tendency of online presidential elections in the USA (Heredia et al., 2018). There is a huge number of them which Iranian and Russian linked 770 bots were suspended by Twitter in August 2018 (Romm, 2018). To find bot accounts on social media accounts of Meydan TV, Radio Liberty, I have used these websites: https://botometer.iuni.iu.edu/\#!/ and https://github.com/IUNetSci/botometer-python.

When I analyze sharing posts of the bots, one feature which discriminates them from real social media users is on their writing style that bots don't utilise natural language. Real social media users do not have the energy and time to obey all the grammar and spelling rules of language. For instance, individuals write as follows: Im, bcs, thats why. 


\section{International Academic Conference on Research in SOCIAL SCIENCES}

However, bots use natural language such as; I am, because, that's why. Text style of bots decreases the efficiency of news to persuade the audience. Because using natural language doesn't create empathy on social media users. Users ignore the troll comments of bots in Facebook or Twitter accounts of Meydan TV.

\section{Language and Patriotism as a propaganda strategy in the Turkic countries of the Caspian Sea region}

The language is another significant factor in propaganda. After the collapse of the Soviet Union, Russia attempts to interfere with the domestic politics of Caspian Sea countries with soft power by making propaganda campaigns. Although Russia continues its orthodox religion propaganda in Georgia, it is not successful in Azerbaijan, Kazakhstan, Turkmenistan because of the atheist population of those countries. In contrast, in postsoviet countries, the old generation talks the Russian language, unlike young people. It assisted for Kremlin to make their propaganda campaigns on Russian speakers. Also, in Kazakhstan, even young generation speak in Russian more than English, which makes them use Russian news as a source. Because Turkey and Iran were losing their power in the Caspian Sea region, thus, both countries started to promote Islam religion through institutions, mosques, however, it did not work because of successful Soviet atheist propaganda. According to Professors G. Mazeikis and R. V. Voren religion arguments have not valid power to make propaganda campaigns in those countries (G. Mazeikis, personal communication, March 25, 2019, \& R. V. Voren, personal communication, May 16, 2019). Therefore, Turkey started to promote the Turkish language, the roots of the Turks, common historical background. Consequently, they launched common TV channels in those Turkish countries, opened Turkish schools, a university in Azerbaijan, Turkmenistan and Kazakhstan which also promote Turkish patriotism. For instances, TV channels such as Trt-Avaz, Trt-Avrasya had different projects, documentary films such as "Ramadan in Kirgizstan", "Carpets of Azerbaijan", "Turkmenistan Diary", "Importance of Kazakhstani horses" etc. In the first vision, those projects can be seen usual programs. However, the audience of Caspian region watches those films which most of them are in the Turkish language. As a result, the number of Turkish speakers arose in recent years. The people of this region started to read Turkish based news. The similarity of the language also helped in orientation to the Turkish language. Conferences, movies, events which shows the Turkic cultures of this region attract the attention of the audience. In a personal interview May 16, 2019, Professor Robert Van Voren noted that "another issue is the Russian language where Putin says I need to defend Russian speaking people because they are citizens. Russian is not an international language like English. All those people have the right to use Russian in their own country. By allowing Putin to claim the Russian language, 


\section{International Academic Conference on Research in SOCIAL SCIENCES

you create a possibility for internal diversity in the country" (R. V. Voren, personal communication, May 16, 2019). As it mentioned in this quote, language is propagated to create internal issues later invade a country by Russia. As, it is obvious to see from examples of language, patriotism is another important factor of propaganda.

\section{The motivation for media manipulation}

As it has been seen above, Turkey attempted and became successful in spreading Turkish ideology, Turkic identity, pan-Turkism. So, first motivation is an ideology, which those mainstream media and others promote their different ideologies. Different ideologies such as socialists, communists are making propaganda against their oppositions. The participants are motivated to share and spread different ideological commitments. For instances, in the Caspian Sea region, promotion of Turkic identity by Turkey can be considered ideological propaganda.

The other motivation is money. RT media channel is funded with $\$ 300$ million per year by the government (Paul \& Matthew, 2016). Radio Liberty in Caspian is funded by the USA to make anti-communist, anti-Russian propaganda. During presidential elections in Azerbaijan, Radio Liberty shares news about corruption, fraud during election processes which take attention of the audience. However, anti-governmental or not pro-governmental media channels don't have governmental sponsor opportunity. Thus, they are obligatory to gain money from advertisements depends on several followers. For instances, the financial source of Meydan TV is provided with the charity by readers. Therefore, the important point is money by taking attention of the audience. (Marwick \& Lewis, 2017).

\section{Conclusion}

Development of modern technology, a rising number of social media users, make the possibility for the government to access and hold propaganda campaigns on society easily. Because of oil and gas resources in post-soviet countries of the Caspian Sea region, make it the focal point of those propaganda campaigns. In this region, contemporary propaganda has strong efficiency because of strategies, techniques, characteristics. Although religion, the economy is not useful for persuasion, propaganda is mainly based on language, patriotism and disinformation in this region. The role of ideology is not significant because the main object of contemporary propaganda is to spread disinformation through cyber troops and psychological basis such as responsive, repetitive, continuous and interpretative techniques. To make clear, by utilizing those mentioned techniques and different types of disinformation such as trolls, fake news via cyber troops and truth is revealed at the third stage of disinformation; it is possible to see that 


\section{International Academic Conference on Research in SOCIAL SCIENCES}

contemporary propaganda is not to persuade a majority of society or is held for a short term. The main aim is to create "Belief Echoes", distract news cycle, or abusing target.

Because the audience has weakness sense of fact-checking, propagandists can easily spread disinformation by using different strategies such as emotional feelings, statistics, experts and witnesses, which strengthen persuasiveness of propaganda. Cyber troops as a propaganda tool assist propagandist to penetrate disinformation easily; however, alsocreates disadvantage. For instance, the absence of the natural language of bots doesn't create empathy on an audience which leads to failure of a propaganda campaign.

To summarize, propaganda campaigns are held according to new technologies, and there is no doubt that it's working principles will evolve as time goes on. In conclusion, Figure 1 shows the working principles of Contemporary Propaganda in the case of postsoviet countries of the Caspian Sea Region. This paper created a framework for further analysis of the methodology of contemporary propaganda.

\section{References}

1. Begg, I. M., Anas, A., \& Farinacci, S. (1992). Dissociation of processes in belief: source recollection, statement familiarity, and the illusion of truth. Journal of Experimental Psychology: General, 121(4), 446.

2. Bradshaw, S., \& Howard, P. (2017). Troops, Trolls and troublemakers: A global inventory of organized social media manipulation. [online]. Available: https://ora.ox.ac.uk/objects/uuid:cef7e8d9-27bf-4ea5-9fd6-855209b3e1f6.

3. De Paoli, S. (2016). The raise of the robots in virtual worlds: A comparison and a framework for investigating bots in social networks sites and MMOGs. [online]. pp. 59-83. Available: https://link.springer.com/chapter/10.1007/978-3-319-220413_2

4. DeSteno, D., Petty, R. E., Rucker, D. D., Wegener, D. T., \& Braverman, J. (2004). Discrete emotions and persuasion: the role of emotion-induced expectancies. Journal of personality and social psychology, 86(1), 43.

5. Fletcher, R., Cornia, A., Graves, L., \& Nielsen, R. K. (2018). Measuring the reach of "fake news" and online disinformation in Europe. [online]. Available: https://www.press.is/static/files/frettamyndir/reuterfake.pdf

6. G. Mazeikis, personal communication, March 25, 2019

7. Hasher, L., Goldstein, D., \& Toppino, T. (1977). Frequency and the conference of referential validity. Journal of verbal learning and verbal behaviour, 16(1), 107112. 


\section{International Academic Conference on Research in SOCIAL SCIENCES}

8. Heredia, B., Prusa, J. D., \& Khoshgoftaar, T. M. (2018, October). The Impact of Malicious Accounts on Political Tweet Sentiment. In 2018 IEEE 4th International Conference on Collaboration and Internet Computing (CIC), pp. 197-202. IEEE.

9. Hindman, M., \& Barash, V. (2018). Disinformation, 'fake news' and influence campaigns on Twitter. [online]. pp13-16. Available: https://www.issuelab.org/resources/33163/33163.pdf

10. Lasswell, H. D. (1927). The theory of political propaganda. American Political Science Review, 21(3), 627-631.

11. Marwick, A., \& Lewis, R. (2017). Media manipulation and disinformation online. [online] pp 27-45. Available: https://apo.org.au/sites/default/files/resourcefiles/2017/05/apo-nid135936-1217806.pdf

12. McCroskey, J. C., \& Young, T. J. (1981). Ethos and credibility: The construct and its measurement after three decades. Communication Studies, 32(1), 24-34.

13. Paul, C., \& Matthews, M. (2016). The Russian "firehose of falsehood" propaganda model. Rand Corporation, 2(7), 1-10

14. Petty, R. E., Cacioppo, J. T., Strathman, A. J., \& Priester, J. R. (2005). To think or not to think. Persuasion: Psychological insights and perspectives, 81, 116.

15. Pomerantsev, P., \& Weiss, M. (2014). The menace of unreality: How the Kremlin weaponizes information, culture and money. New York: Institute of Modern Russia.

16. R. V. Voren, personal communication, May 16, 2019

17. Romm, T. (October 2018). Iranians masqueraded as foreign journalists to push political messages online, new Twitter data shows. [online]. Available: https://www.washingtonpost.com/technology/2018/10/17/new-data-show-howiran-tried-manipulate-public-opinion twitter/?noredirect=on\&utm_term $=.86 \mathrm{~d} 251 \mathrm{fb} 2 \mathrm{~b} 8 \mathrm{~d}$

18. Russia Today. (March 2019). Kazakh president Nursultan Nazarbayev, a key Russian ally, resigns after almost 30 years in power. [online]. Available: https://www.rt.com/news/454200-kazakhstans-president-nazarbayev-resigns/

19. Speier, H. (1950). Historical development of public opinion. American Journal of Sociology, 55(4), 376-388.

20. Thorson, E. (2016). Belief echoes: The persistent effects of corrected misinformation. Political Communication, 33(3), 460-480. 


\title{
International Academic Conference on Research in
}

SOCIAL SCIENCES

8 - 10 November, 2019

OXFORD, UNITED KINGDOM

\begin{abstract}
ANNEX 1
Interview with Professor Gintautas Mazeikis. (2019/04/25)

$1^{\text {st }}$ question. Can you please tell us about your academic background and if you have or had, practical experience with propaganda?
\end{abstract}

Prof. G. Mazeikis: I am a philosopher graduated from Leningrad later Saint Petersburg University. I was involved in analysis and studies of symbolical forms of thinking. During the Soviet period, I choose analysis of propaganda. So, I was completely involved into counter-propaganda in Western countries later I cared about war and different source of persuasion beginning from Perestroika starting from 1986, so I could follow the development of a whole period of Soviet, Lithuanian and finally contemporary European propaganda. I am doing practical analysis for different companies and Lithuanian government. Sometimes I am involved as an expert of some group in NATO.

\section{$2^{\text {nd }}$ question. What are the main factors of successful propaganda in the case of the Caspian Sea region?}

Prof. G. Mazeikis: I would say everything depends on the skills of the audience and your purposes or objectives which you would like to achieve and on the instruments which you use. Because audiences are different everywhere, and they are mostly influenced by religious persuasion before. It means, if you would like to turbulent people or just stop them, you could use religious arguments. It is different from Western countries where the economical system is more painful. For example, what western countries care is about banks, accounts, the situation of the economy but not about religious solutions. Ukraine is in some kind of mixed situation where economical and religious issues and also a national idea. What I see about the Caspian Sea region like Kazakhstan, Azerbaijan, I would say the case of Kazakhstan is a little bit different because all this information is not for a large audience. Because nobody cares about masses so-called population in Russia or Kazakhstan. They did not pay attention about the manipulation of the population. This is information for elites. (News I mentioned above about resignation of Nazarbayev). These elites should be quite peaceful and no any attempt to change the political situation. Kazakhstan and Russia cares about the peaceful transformation of this Kazakh power. And the main argument for leaders of these oligarchs is economy because the benefits of those elites $90 \%$ or $80 \%$ depends on the relationship between Russia and Kazakhstan. 


\section{International Academic Conference on Research in SOCIAL SCIENCES

Azerbaijan is different from Kazakhstan. Because it was about public intellectuals, a critique of Azerbaijan power and corruption. Corruption is in everywhere but at different levels and this is the problem of all post-soviet countries. Hierarchy has a really strong power in Azerbaijan. And they follow this idea that only we can fight against corruption but not public intellectuals or local initiatives. This news was not only addressed for elites but also for public intellectuals such as teachers, a journalist who would like to have freedom. These ideas don't work for society. Because both sides say that we are fighting against corruption, but masses don't believe any fight. I would say these both cases are not about mass propaganda or manipulation of masses. They don't need to use any religious arguments or banking system in these cases because it is about corruption and freedom of speech.

\section{Interview with Professor Robert Van Voren (16/052019)}

$1^{\text {st }}$ question. Can you please tell us about your academic background and if you have or had, practical experience with propaganda?

Prof. R. V. Voren: I started political life as a human right activist in the Soviet Union, international relations, Helsinki records. My experience with propaganda is two periods: Soviet and current period. I started my activism from 1977 combating with Soviet propaganda. I can compare that period with what is happening right now. I would say propaganda is the same, but the methodology is different because of modern technology. Currently, my interest mostly focuses on Ukraine because I was active in Maidan and I know details what happens after Ukrainian war and also on Georgia because I have been teaching since 2010 and because of Russian-Georgian war.

$2^{\text {nd }}$ question. What are the main factors of successful propaganda in the case of the Caspian Sea region?

Prof. R. V. Voren: I think if we go back what was then and is now, the big difference is that the Soviet period had an ideological base. So the soviet period was very active with peace movement supporting peace movement in the West not only

financially also ideologically. Now you see that propaganda has no ideological base. But key elements here is as if Russia is surrounded by enemies. It is the same when we go back to 1920, Stalin created the same scenery. But now there is no ideological basin.

Creating an image of an external enemy is very successful in persuading people to calm down their opposition and ban certain media, which are the friends of human 


\section{International Academic Conference on Research in SOCIAL SCIENCES}

rights. Also, through external enemy scenery, you can find arguments for economic problems.

One particular example for me is the Russian language. Putin is very good in rewriting history. One example, he claims that Russia lost 23 or 30 million people in the $2^{\text {nd }}$ World War. If you look at the facts, the largest lose percentage belongs to Belarussians and Ukrainians. But he counts Ukrainians, Belarussians together as a Russians. And people don't check the facts. Another one is the Russian language where Putin says I need to defend Russian speaking people because they are citizens. Russian is not an international language like English. All those people have the right to use Russian in their own country. By allowing Putin to claim the Russian language, you create a possibility for internal diversity in the country. After Maidan, Russian became the language of the oppressor, the language of the country invaded Ukraine, occupied Crimea. Russian is also the language of Andrey Sakharov, dissidents who are in jail. So, Russia is very good to create tensions by using modern technology and making some issues which shouldn't be an issue.

\section{ANNEX 2}

Figure 1. Map of working principles of Contemporary Propaganda in the case of post-soviet countries of the Caspian Sea Region.

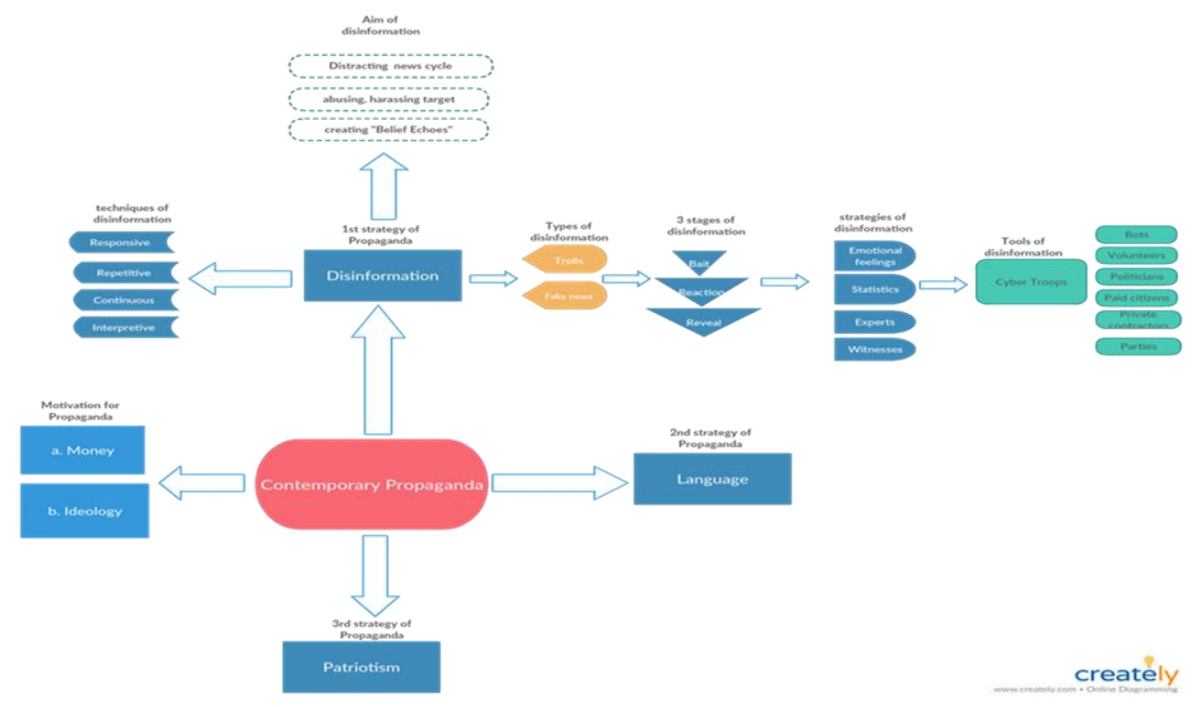

